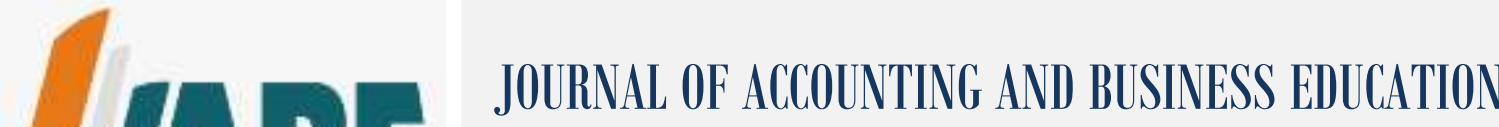 \\ P-ISSN 2520-7201 E-ISSN 2528-729X \\ E-mail: jabe.journal@um.ac.id \\ http://journal2.um.ac.id/index.php/jabe/
}

\section{An Exploration of Indonesian Accounting Education Practices}

\author{
Ika Rahmawati ${ }^{1}$ \\ Ani Wilujeng Suryani ${ }^{2}$ \\ ${ }^{1,2}$ Accounting Department, Faculty of Economics, Universitas Negeri Malang, Indonesia \\ email: ani.suryani@um.ac.id
}

DOI: http://dx.doi.org/10.26675/jabe.v6i1.19422

Abstract: This study reviewed the development of accounting education research in Indonesia for 21 years. The reviews were conducted on 428 accounting education articles in the nationally accredited journals from 1999 to 2019. A bibliometric approach and content analysis were used to analyze the articles' topics, theories, methods, and characteristics. This study also separated the period of 21 years into two decades. The results show that accounting education research topics revolved on curriculum and teaching, content-based teaching, educational technology, students and faculty dominated by many quantitative studies. T-test, regression, and path analysis were the most commonly used data analysis techniques. However, only 86 articles framed the studies with the common behavioral, motivational, and fraud theories. Interestingly, some articles used the "gone theory" which actually never existed. Based on the topic classifications, "students" were the most frequently discussed subjects, followed by the content-based teaching, curriculum and teaching, and lastly teaching staff and educational technology. The results of this study suggest that more studies on accounting curriculum should be conducted emphasizing on technology for the accounting education 4.0.

\section{Article History}

Received:

23 February 2021

Revised:

19 June 2021

Accepted:

19 June 2021

\section{Keywords}

Accounting Education; Accounting Literature; Article Review; Bibliometrics; Content Analysis

Citation: Rahmawati, I., \& Suryani, A. W. (2021). An Exploration of Indonesian Accounting Education Practices. Journal of Accounting and Business Education, 6(1), 32-48

\section{INTRODUCTION}

The massive development of financial world has become an important reason to gain more knowledge in the field of accounting education (Acar \& Aktaş, 2018). However, the accounting education system still faces various substantial obstacles since failing to adapt the environmental changes (Albrecht \& Sack, 2000; Freeman et al., 2008; Pathways Commission, 2015). Since the middle of 1980, professional accounting bodies and academicians have criticized the accounting education curriculums which failed to equip graduates with the competencies required by the accounting profession in modern era (Botha, 2001; Bui \& Porter, 2010; Howieson, 2003; Parker, 2001; Pathways Commission, 2015b). Therefore, the accounting academicians are required to improve and adapt the accounting education to the development of financial world and the existing businesses (Albrecht \& Sack, 2001; Ekasari et al., 2016). 
Studies related to the trends of accounting education have been conducted by many researchers (such as Apostolou et al., 2001; Rebele et al., 1998a, 1998b; and Rebele et al., 1991). The research studies examined the empirical research and summarized the existing research directions by providing recommendations for future research. Of all studies examining trends in accounting education research, there is a fairly comprehensive research conducted by Apostolou et al. The research was inspired by Apostolou et al. (2019) examining the development of accounting education in five best international journals. The research period started in 1997-1999 (Apostolou et al., 2001), 2000-2002 (Watson et al., 2003), 2003-2005 (Watson et al., 2007), 2006-2009 (Apostolou et al., 2010), 2010-2012 (Apostolou et al., 2013), 2013-2014 (Apostolou et al., 2015), 2015 (Apostolou et al., 2016), 2016 (Apostolou et al., 2017), 2017 (Apostolou et al., 2018), and 2018 (Apostolou et al., 2019). The results showed that the accounting education studies shifted from descriptive to more empirical, but the reviewed discussion was not equivalent to educational research, such as in the fields of psychology and education (Apostolou et al., 2013, 2017b).

In Indonesia, there are studies exploring the development of trends in the field of accounting. Kuang (2010) discussed the article reviews on behavioral accounting updated by Tin (2017). The research results showed that behavioral accounting research was dominated by behavior changing strategies, subjects-affecting treatments, and behavioral accounting influences. Susilo (2014) has examined the development of Corporate Social Responsibility in Indonesia and found that the corporate social performance reporting in the annual report was not yet optimal and only limited on narrative commitments. Meanwhile, Herawati \& Bandi (2019) found that universities dominated the authors' institutional affiliations and only few studies were conducted in the field of taxation. In addition, similar research in the field of interpretive accounting showed that the accounting practices related to people, culture, and religion were used as reasons mentioning that interpretive paradigm was an appropriate research method. However, the number of interpretive accounting studies in Indonesia were still very limited when compared to the dominance of positive research (Darmayasa \& Aneswari, 2015). Furthermore, researchers in the field of statistical analysis have found that most of scientific articles had used the basic principles suggested in conducting the survey research, although there were still some aspects should be well notified to improve the quality of survey data (Aryani et al., 2014). The study on qualitative accounting research analysis belonging to Suryani (2018) found that the qualitative research data collection was mostly conducted using interviews. Many articles used more than two types of triangulation methods, but most articles did not explain how data collection was performed. The accounting management research has formed the domination of particular topics on information related to planning and control (Ratnaningrum et al., 2018).

The research trends were also studied in the fields of earnings management and banking. Suprianto \& Setiawan (2017) found that the antecedent of earnings management is a topic extensively discussed using the analytical method and modified Jones accruals model. In banking sector, the topic on bank performance was the most common topic discussed in various research studies using the analytical research methods, while the variable widely used in measuring performance was return on assets (Suryaputra et al., 2017). However, no research has been found discussing the development of accounting education research in Indonesia. In fact, many related researches have been conducted by various researchers in America and Turkey (Acar \& Aktaş, 2018; B. Apostolou, Dorminey, Hassell, \& Hickey, 2019). In addition, there were only 3 Indonesian journals focusing on accounting education covering Journal of Accounting and Finance Education, ASSETS: Journal of Accounting and Education, and Journal of Accounting and Business Education. (Sinta Ristekdikti, 2019).

Thus, this research analyzed the existing studies on accounting education in Indonesia by understanding the research trends to figure out the implementation of accounting education in the last two decades as well as opportunities or future research gaps. In addition, an analysis focusing on one topic was greatly important in evaluating the accounting academicians' performance (Bonner et al., 2006). 


\section{METHODS}

This research was a literature review using a systematic literature review, with a bibliometric analysis approach and content analysis. This research was different from the traditional literature reviews since the systematic literature reviews emphasized more on a systematic, transparent way to collect, synthesize, and assess the research findings (Sweet \& Moynihan, 2007). The bibliometric analysis was greatly beneficial to determine the research trends using databases (Kalantari et al., 2017; Kurtz \& Bollen, 2012). Content analysis was used to examine the research findings obtained from the accounting education trends in Indonesia. Meanwhile, content analysis used a coding process or organized many texts into smaller categories (Weber, 1990). Figure 1 shows the research designs used.

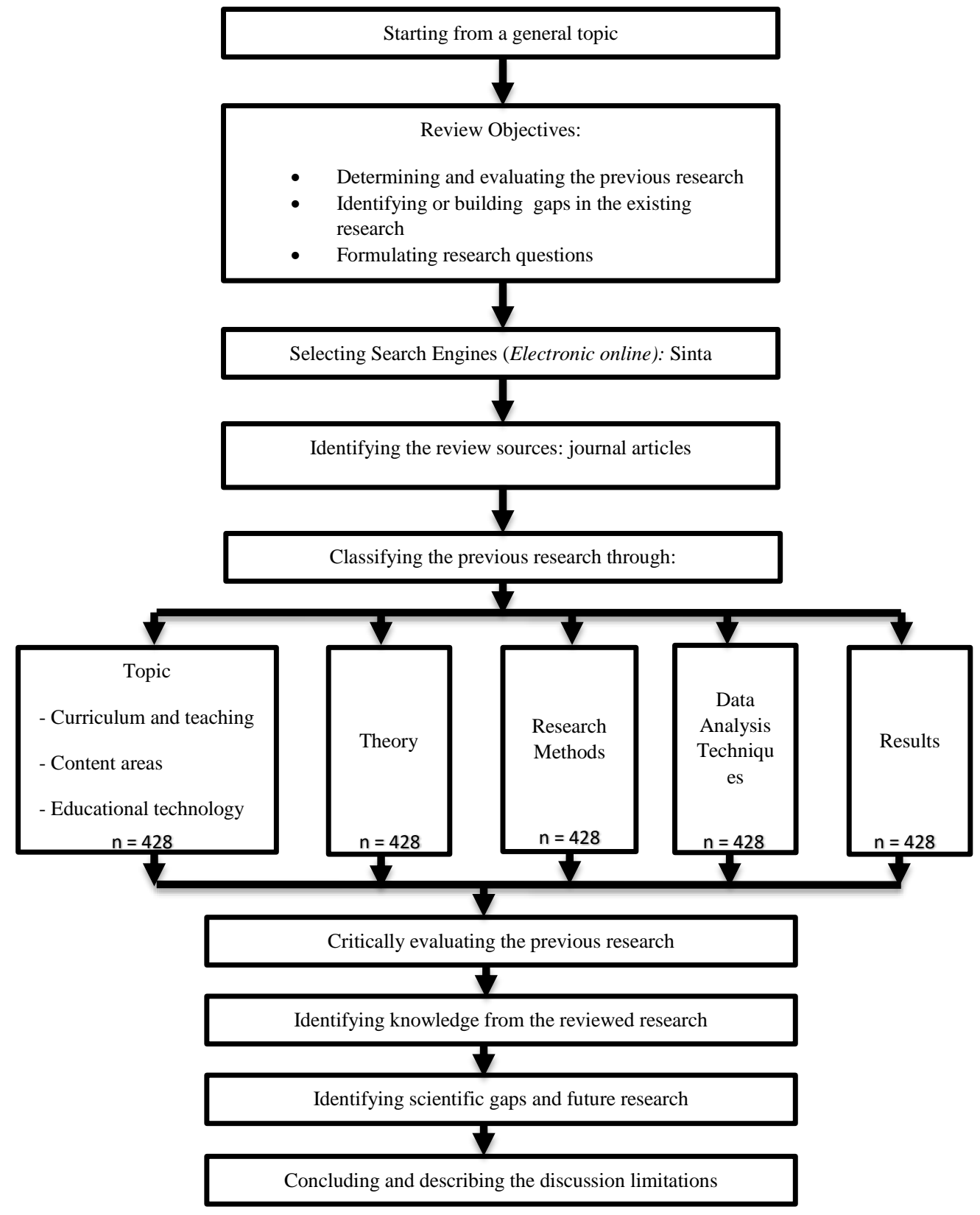

Figure 1. Research Design

(Adapted from Apostolou et al., 2019 and Hoque, 2014) 
This study used the secondary data from the database of Science and Technology Index (Sinta). Sinta is used as the basis for the first data selection because 1) Sinta is a portal to measure the performance of science and technology developed by the Ministry of Research, Technology, and Higher Education (known as Kemenristekdikti), 2) Sinta leads to global (international) indexing portals, such as Scopus, Google Scholar, Indonesia Science, and Technology Index (InaSTI) as well as Indonesian Publication Index (IPI), 3) Researchers registered in Sinta cover almost all educational institutions in Indonesia, 4) Articles in the portal are the results of credible and accountable reviews. Thus, the data used in this study were valid and reliable. The article searching was focused on journals discussing the accounting education using the keywords of "Pendidikan Akuntansi (Accounting Education)", "Pendidikan (Education)", "Akuntansi (Accounting)", "Accounting Education" and "Accounting". Table 1. was briefly used in the literature searching as follows.

Table 1. Article Searching Criteria

\begin{tabular}{|c|c|c|}
\hline Criteria & & Description \\
\hline Period & 1997-2019 & 23 observation years \\
\hline Language & Indonesia & Most articles were published in Indonesian Language \\
\hline Publication Type & Journal Articles & $\begin{array}{l}\text { Only the empirical articles were discussed in this } \\
\text { research }\end{array}$ \\
\hline Geographical Location & Indonesia & All accounting educational research in Indonesia \\
\hline Article Searching Limits & 4 January 2020 & \\
\hline
\end{tabular}

The data collection processes were performed in several stages. First, the authors selected journals providing the open-source articles consisting of articles which are free from access restrictions, such as fees and use restrictions (Suber, 2015). The article searching was started by searching the journals registered in Sinta using the keywords of "Pendidikan Akuntansi (Accounting Education)" ( $\mathrm{n}=1)$, "Pendidikan (Education)" ( $\mathrm{n}=37)$, and "Akuntansi (Accounting)" and "Accounting" $(\mathrm{n}=71)$. The authors then opened the webpages of these 109 journals.

In the next process, the authors read each article title in each journal to filter the relevant accounting education articles. The criteria for articles to be saved from the educational journals were those with titles having the accounting elements. In the accounting journals, the selected articles were those having the elements related to pedagogy, curriculum, and educational technology, teaching staff, and learning evaluation. The downloaded articles were then classified into four article types consisting of empirical articles $(n=428$, which conclusions were drawn from the data analysis; descriptive articles $(\mathrm{n}=132$, which discussed strategies, described innovations, reported the student perceptions without statistical analysis); instructional resource articles $(n=83$, which discussed pedagogy to facilitate teaching and promote learning for students) and case study articles $(n=37$, which discussed actual or hypothetical situations requiring analysis on students).

In this study, the authors focused on the empirical articles because this type of articles were conducted using a scientific method involving the empirical data analyzed through data analysis techniques prioritizing facts occurring in the field. In addition, the information contained in the empirical articles is easy to observe because the research results were based on experiences, experiments, and observations made by the researchers. Third, the researchers who were considered as the references for this research used empirical articles as the review sources (Apostolou et al. 2017b).

The last step was summarizing the contents of empirical articles assisted by Microsoft Excel which used content analysis to examine each classification determined using the filter feature and then discussed those research findings. The research aspects described in this mapping process were in accordance with what the authors found unique to discuss (Richter et al., 2020, 16). The complete article searching results can be seen in Table 2 as follows. 
Table 2. Searching Results of Education and Accounting Journal Articles

\begin{tabular}{|c|c|c|}
\hline No & Criteria & $\begin{array}{c}\text { Number of } \\
\text { Articles }\end{array}$ \\
\hline \multicolumn{3}{|c|}{ Panel A. Accounting Education Journals } \\
\hline 1 & Articles in "education" journals & 6.592 \\
\hline 2 & After-Reading Relevant Articles & 136 \\
\hline 3 & The empirical article classifications Used & 84 \\
\hline \multicolumn{3}{|c|}{ Panel B. Accounting Journals } \\
\hline 1 & Articles in "accounting" journals & 11.719 \\
\hline 2 & After-Reading Relevant Articles & 544 \\
\hline 3 & The empirical article classifications Used & 344 \\
\hline
\end{tabular}

\section{RESULTS AND DISCUSSION}

The research results showed that the accounting education articles on market share were respectively $2 \%$ in "education" journals and 5\% in "accounting" journals throughout Indonesia for 23 years. The low publication number of accounting education articles may be due to the lack of or some research conducted on accounting education, yet not published in journals. This could be seen from Sinta databases showing that there were only 3 (three) accounting education journals and 69 accounting journals. This finding was a great opportunity for the accounting researchers to develop research related to accounting education and publish theirs in the nationally accredited journals. In addition, the accounting education study program could also create and manage journals related to the accounting education topics to ease researchers to find and publish their research in the field of education as well as competition with the overseas journals.

Figure 1 shows that the article publications have significantly increased starting in 2013 due to the obligation of S1/S2/S3 students and graduates to publish their articles (Dikti, 2012; Permenristekdikti, 2015). In 2017, the graph showed that scientific publications had experienced a significant increase when compared to those in the previous years. This was related to the Higher Education National Standard (known as SN Dikti) in master, doctoral and applied doctoral programs (see the Circular Letter Number 444/B/SE/2016). The efforts made to increase the scientific publications were intended to communicate the research results to the wider communities, become the bases for future research, improve the quality and quantity of national and international publications, and provide contributions to the development of science and technology to improve the competitiveness of the nation.

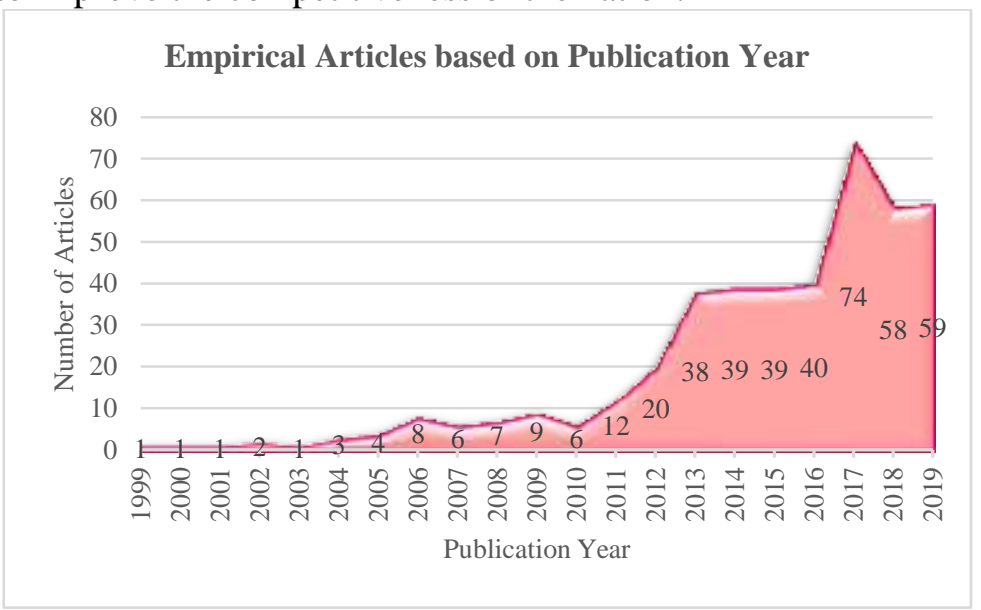

Figure 1. Trend of empirical article development within two decades

The empirical articles contained in the accounting education journals were mostly written by two authors (47\%), followed by one author (28\%), three authors (24\%), and more than three authors (1\%). 
These results were relevant to the findings of research conducted by some previous researchers (Ameen \& Guffey, 2017; Apostolou et al., 2019; Carnegie \& Potter, 2000; Lukka \& Kasanen, 1996), while the number of researchers in the accounting field mostly consisted of two authors and rarely consisted of three authors. It means that the level of collaboration between the accounting education researchers at different universities was still minimum supported by the research conducted by Lindsey and Brown (in Garfield, 1979) mentioning that collaboration in economics, social, and sociology ranged from 17-25\%, while in gerontology, psychiatry, psychology, and biochemistry, it reached 48-81\%. In addition, the accounting article publications in the highly reputable journals tended to be lack of collaboration as the objective was to improve the quality of authors' reputation (Rutledge \& Karim, 2009).

However, basically there are many advantages that can be obtained from research collaboration, such as creating opportunities to share knowledge, expertise, and certain techniques in a particular science (Katz \& Martin, 1997). In addition, collaboration between researchers increases the research competitiveness through collaboration between universities and foreign researchers (Ristekdikti, 2018; Wisnubro, 2019). It means that the more often researchers make collaboration, the quality and quantity of the published scientific papers may increase due to the encouragement or motivation to exchange ideas and interactions between researchers and other scientists in adding new insights and perspectives. Collaboration may not only encourage creativity from the researchers to become more creative in conducting the linear or cross-disciplinary research to continuously develop the topic on accounting education.

\section{Theories}

Table 4 shows the classification of articles in accordance with the theories used. Data analysis shows that of 428 empirical articles, only $20 \%$ used the related theories. In fact, the high quality research comes from that connected with the theories (Neuman, 2014, 88). Theories provide the basic concepts in logical frameworks, connecting research with knowledge (knowledge-based research) contributed by the other researchers, deepening the discussion, enriching analysis, and increasing the researchers' awareness related to the importance of broader data (Neuman, 2014, 55). Therefore, future research should consider the use of theories to result in stronger studies enriched with the existing literatures.

Table 4. Classifications based on the theories used

\begin{tabular}{|c|c|c|c|}
\hline No & Theory & Article (n) & Article \% \\
\hline 1 & $\begin{array}{l}\text { Planned behavior, reasoned action, Technology Acceptance } \\
\text { Model (TAM), Expectation, Social cognitive career, } \\
\text { perception, Holland, Hygiene }\end{array}$ & 43 & $49 \%$ \\
\hline 2 & $\begin{array}{l}\text { Motivation, Maslow human basic needs, humanistic } \\
\text { psychology }\end{array}$ & 14 & $16 \%$ \\
\hline 3 & Fraud triangle, Fraud diamond & 12 & $14 \%$ \\
\hline 4 & Constructivism, Morality Development Theory & 4 & $5 \%$ \\
\hline 5 & Contingency Theory & 3 & $3 \%$ \\
\hline 6 & Attribution theory & 2 & $2 \%$ \\
\hline 7 & Gone Theory & 2 & $2 \%$ \\
\hline 8 & Others & 7 & $7 \%$ \\
\hline 9 & Number of articles & 87 & $100 \%$ \\
\hline 10 & Empirical articles Percentage using theories (87/428) & & $20 \%$ \\
\hline
\end{tabular}

The theories which were more frequently used in the accounting education research were respectively behavioral theory $(n=43)$, motivational theory $(n=14)$, and fraud theory $(n=12)$. This was because the accounting education research tended to use the students as the research samples and many researchers were interested in examining the students' behavioral patterns. Therefore, the findings related to the accounting education research trends were mostly on research utilizing the behavioral theories 
which were actually derived from the field of psychology and rarely used the learning theories. In addition, there were two authors using gone theory in accordance with the citations used by many authors in Indonesia revealing that this theory was developed by G. Jack Bologna in his book entitled The Accountant Handbook of Fraud and Commercial Crime adapted by BPKP12 in the National Corruption Eradication Strategy book 1999 (Tirto, 2011). Thus, many citations only included G. Jack Bologna, yet in facts the complete book was compiled by G. Jack Bologna, Robert J. Lindquist, and Joseph T. Wells. Based on these findings, many authors explained that factors causing fraud in performing the collusion and corruption include Greeds, Opportunities, Needs, and Exposures. However, after searching further using the Google Scholar search engine, the authors did not find any data supporting the truth obtained from this theory. The Fraud Auditing and Forensic Accounting edition 13 written by Tommie Singleton, Aaron Singleton, Jack Bologna, and Robert Lindquist had no discussion related to gone theory, but fraud taxonomy, that is, fraud coming from both internal and external companies (Singleton et al., 2007, 29). Therefore, the relevance of this theory still needs to be further investigated to ensure whether or not this theory is true.

\section{Methods}

The research findings show that survey has become the most popular empirical research approach $(n=356,83.2 \%)$ and then followed by experimental $(n=41,9.6 \%)$. Meanwhile, the other types of approaches were presented in

Table . This is due to easier and cheaper access to the data sources. In addition, survey was frequently used since flexible to measure attitudes, knowledge, preferences, and interests in certain social groups; had the characteristics with certain standards so that the error diversity levels in providing opinions can be avoided; easy to run; in accordance with the phenomena intended by the authors to study (Yuliansyah, 2016). Experimental methods were frequently used as the research results provided were more precise and relatively unambiguous evidence for the causal relationships, easier to perform, as well as inexpensive and took less time than the other research methods (Neuman, 2014). From time to time, the types of approaches used by the accounting education researchers are increasingly various. It means that there is an increasing quality and ability of researchers in developing their research in accordance with time. This is supported by the government programs which continuously encourage educators to improve their bachelor (S1), magister (S2), and doctoral (S3) education as well as professors. In addition, the government also awarded some appreciations in the form of research funding subsidies to maximize the educators' capacity.

Table 5. Research Methods used

\begin{tabular}{|c|c|c|c|c|c|c|c|c|}
\hline \multirow[b]{2}{*}{ No } & \multirow[b]{2}{*}{$\begin{array}{c}\text { Approach } \\
\text { type }\end{array}$} & \multirow[b]{2}{*}{$\begin{array}{c}\text { Total } \\
\text { Articles }\end{array}$} & \multicolumn{5}{|c|}{ Article (n) } & \multirow[b]{2}{*}{$\begin{array}{c}\text { Article } \\
\%\end{array}$} \\
\hline & & & $\begin{array}{l}\text { Curriculum } \\
\text { \& Teaching }\end{array}$ & $\begin{array}{l}\text { Topic- } \\
\text { based } \\
\text { Teaching }\end{array}$ & $\begin{array}{l}\text { Educational } \\
\text { Technology }\end{array}$ & Students & $\begin{array}{c}\text { Teaching } \\
\text { Staff } \\
\text { (Faculty) }\end{array}$ & \\
\hline 1 & Survey & 356 & 49 & 94 & 19 & 154 & 40 & $83.2 \%$ \\
\hline 2 & Experiment & 41 & 21 & 11 & 7 & 1 & 1 & $9.6 \%$ \\
\hline 3 & Descriptive & 13 & 4 & 4 & 0 & 5 & 0 & $3.0 \%$ \\
\hline 4 & Explanatory & 7 & 2 & 1 & 1 & 2 & 1 & $1.6 \%$ \\
\hline 5 & Others & 11 & 5 & 3 & 0 & 3 & 0 & $2.5 \%$ \\
\hline \multicolumn{2}{|c|}{ Number of articles } & 428 & 81 & 113 & 27 & 165 & 42 & $100 \%$ \\
\hline
\end{tabular}

Regarding the data collection techniques, documentation was the most frequently used method $(\mathrm{n}=283,66.1 \%)$, questionnaire $(15.7 \%)$, test $(1.9 \%)$, and combined method (See Table 66). The use of documentation and questionnaire for data collection techniques generally does not require expensive costs in contrast to interview which requires the relatively expensive costs. In addition, the problems related to 
time are sometimes difficult to match the interviewers' schedules to interview the informants. Thus, interview actually takes a longer time when applied to a wider range of certain area.

Table 6. Data Collection Techniques Used

\begin{tabular}{|c|c|c|c|c|c|c|c|c|}
\hline \multirow[b]{2}{*}{ No } & \multirow[b]{2}{*}{$\begin{array}{c}\text { Data } \\
\text { Collection } \\
\text { Technique }\end{array}$} & \multirow[b]{2}{*}{$\begin{array}{c}\text { Total } \\
\text { Articles }\end{array}$} & \multicolumn{5}{|c|}{ Article (n) } & \multirow{2}{*}{$\begin{array}{c}\text { Article } \\
\%\end{array}$} \\
\hline & & & $\begin{array}{l}\text { Curriculum } \\
\text { \& Teaching }\end{array}$ & $\begin{array}{c}\text { Topic- } \\
\text { based } \\
\text { Teaching }\end{array}$ & $\begin{array}{l}\text { Educational } \\
\text { Technology }\end{array}$ & Students & $\begin{array}{c}\text { Teaching } \\
\text { Staff } \\
\text { (Faculty) }\end{array}$ & \\
\hline 1 & Documentation & 83 & 23 & 80 & 17 & 133 & 30 & $66.1 \%$ \\
\hline 2 & Questionnaire & 67 & 12 & 21 & 3 & 22 & 9 & $15.7 \%$ \\
\hline 3 & Test & 8 & 5 & 2 & 1 & 0 & 0 & $1.9 \%$ \\
\hline 4 & Two methods & 18 & 8 & 4 & 2 & 3 & 1 & $4.2 \%$ \\
\hline 5 & $\begin{array}{l}\text { More than two } \\
\text { methods }\end{array}$ & 52 & 33 & 6 & 4 & 7 & 2 & $12.1 \%$ \\
\hline \multicolumn{2}{|c|}{ Total articles } & 428 & 81 & 113 & 27 & 165 & 42 & $100 \%$ \\
\hline
\end{tabular}

\section{Data Analysis Techniques}

Based on the classification of data analysis techniques, the most frequently used analysis technique was respectively regression $(\mathrm{n}=226,52.8 \%)$, discriminant test $(\mathrm{n}=79,18.5 \%)$, path analysis $(\mathrm{n}=53,12.4$ $\%)$, non parametric $(n=16,3.7 \%)$, descriptive $(n=10,2.3 \%)$, and correlation $(n=8,1.9 \%)$ (See Table ). Regression is a statistical analysis instrument which was frequently used by the researchers (Kurniawan, 2016). These results were consistent with the research conducted by Apostolou et al. (2017b) mentioning that regression, discrimintion test, and path analysis were more frequently used in the accounting education research than those performed in the past decades. When compared to the first decade, the analysis techniques used by the accounting education researchers tended to be various from time to time along with the continuously increasing scientific article publications made by the researchers. This is due to the continuously increasing quality and ability of researchers to develop their research in meeting the demands of the present era. The government also supported and encouraged educators through various programs to improve education and appreciation programs in the form of research funding subsidies (Simlitabmas ristekdikti, 2017) aiming to increase the capacity of educators to to compete with foreign researchers.

Table 7. Data Analysis Techniques Used in the Empirical Articles

\begin{tabular}{|c|c|c|c|c|c|c|c|c|}
\hline \multirow[t]{2}{*}{ No } & \multirow{2}{*}{$\begin{array}{l}\text { Data Analysis } \\
\text { Techniques }\end{array}$} & \multirow{2}{*}{$\begin{array}{c}\text { Total } \\
\text { Articles }\end{array}$} & \multicolumn{5}{|c|}{ Number of Articles } & \multirow{2}{*}{$\begin{array}{c}\text { Article } \\
\%\end{array}$} \\
\hline & & & $\begin{array}{l}\text { Curriculum } \\
\& \text { Teaching }\end{array}$ & $\begin{array}{c}\text { Topic- } \\
\text { based } \\
\text { Teaching }\end{array}$ & $\begin{array}{l}\text { Educational } \\
\text { Technology }\end{array}$ & Students & $\begin{array}{l}\text { Teaching } \\
\text { Staff } \\
\text { (Faculty) }\end{array}$ & \\
\hline 1 & $\begin{array}{l}\text { Regression and its } \\
\text { Derivations }\end{array}$ & 226 & 36 & 49 & 10 & 111 & 20 & $52.8 \%$ \\
\hline 2 & Discrimination Test & 79 & 19 & 30 & 10 & 15 & 5 & $18.5 \%$ \\
\hline 3 & $\begin{array}{l}\text { Path Analysis (PLS, } \\
\text { SEM) }\end{array}$ & 53 & 10 & 9 & 4 & 20 & 10 & $12.4 \%$ \\
\hline 4 & Non Parametric & 16 & 1 & 10 & 1 & 3 & 1 & $3.7 \%$ \\
\hline 5 & Descriptive & 10 & 4 & 3 & 2 & 1 & 0 & $2.3 \%$ \\
\hline 6 & Correlation & 8 & 2 & 0 & 0 & 5 & 1 & $1.9 \%$ \\
\hline 7 & Factor Analysis & 3 & 0 & 0 & 0 & 3 & 0 & $0.7 \%$ \\
\hline 8 & $\begin{array}{l}\text { More than two } \\
\text { methods }\end{array}$ & 33 & 8 & 13 & 0 & 7 & 5 & $7.7 \%$ \\
\hline Tot & articles & 428 & 80 & 114 & 27 & 165 & 42 & $100 \%$ \\
\hline
\end{tabular}

\section{Topics in Accounting Education}

The contributions in empirical articles were mostly dominated by the topic on curriculum and teaching $(19 \%, \mathrm{n}=81)$, content-based teaching $(26 \%, \mathrm{n}=113)$, educational technology $(6 \%, \mathrm{n}=27)$, students $(39 \%, \mathrm{n}=165)$, and teaching staff (faculty) $(10 \%, \mathrm{n}=42)$. The empirical articles in the second 
decade were greater than those in the first decade. This finding was consistent with that of research conducted by Apostolou et al. (2017b), mentioning that the most contributing topic was student followed by curriculum and teaching, teaching staff, content-based teaching, and educational technology. These phenomena occurred as the accounting education research reviewed many articles with the topics on pedagogy, curriculum, and educational evaluation at universities and schools by involving academicians as the research subjects.

Trend analysis documented the continuously increasing number of articles over the past two decades (1999-2019). The proportion of the analyzed articles with all topic classifications had a difference in number within a period of two decades, and the variation related to the number of articles was very large. It shows that the accounting researchers were already involved in various topics. Therefore, the analysis on each topic was conducted by examining the variables constructing the accounting education research for two decades.

\section{Curriculum and teaching}

During the processes of exploring the empirical articles on the topic of curriculum and teaching $(n=81)$, learning assurance and score were the most topic frequently studied $(n=37,46 \%)$, followed by core competency $(n=15,19 \%)$, curricular problem $(n=17,25 \%)$, and instructional approach $(n=12,15 \%)$. Meanwhile, the percentage change in the publication of curriculum and teaching articles for two decades was $575 \%$, in which the average articles published annually in the first and second decade were respectively 1.2 and 6.8. These results indicate that the proportion of curriculum and teaching articles in the first and second decade were different.

The knowledge bases developed by those 37 empirical articles which were on the subtopics of learning assurance and assessment tended to focus on classroom assessment and factors ensuring the learning objectives had been well fulfilled. This assessment could be seen on how to manage the classrooms (Arumsari, 2017; Gunawan \& Herawati, 2018; Handayani, 2015), experiments on learning media (Anisa \& Yulianti, 2013; Fauziah et al., 2018; Herawan \& Rahayu, 2016; Kurniawan, 2017; Wulansari, 2012; Yulizah \& Yuliyanti, 2015), additional learning hours (Febriyanti et al., 2014), and teachers' teaching quality (Alamsyah, 2013; Riddiniyah, 2013; Utami, 2015), in which the research objects were dominated by the high school and vocational school students.

Higher education did not only emphasize the students' understanding on technical but also on conceptual competence when performing practices in the field (Suryarini, 2009). Therefore, the values of individuality, social, critical thinking, and financial management abilities were an individual's core competencies (Anggon et al., 2006; Laksmi \& Febrian, 2018; Merdekawaty \& Fatmawati, 2019; Suryaningsum et al., 2005; Suryarini, 2009). In addition, many researchers in the field of accounting education focused on discussing approaches in teaching using the classroom action research, such as the use of learning models covering deep dialogue-critical thinking (DD-CT), modules, offline and online games, cases, peer approaches, and quantum teaching (A'yuni \& Wibowo, 2014; Luhsasi, 2017; Mutmainah, 2008; Purnamasari et al., 2014; Suratno, 2009; Tanuadmodjo \& Samlawi, 2014; Yana \& Novitasari, 2015). The results of this study also show that only a few researchers discussed the topic on accounting curriculum which was not in accordance with the needs of business world in it relationship with skills or Statements of Financial Accounting Standards (known as PSAK/ Pernyataan Standar Akuntansi Keuangan) (Afriyenti \& Misra, 2019; Estiningsih, 2014).

The results of comparison between research in Indonesia and that conducted by Apostolou et al. (2017b) for two decades in international journals show that Indonesian researchers tended to have various learning approaches. However, when compared to the research on accounting education at the international level, there was still minimal research emphasizing on curriculum integrated with technology. Therefore, research on accounting education provided broader opportunities to empirically explore the interrelationships between learning styles, students' characteristics, and cultures in improving the learning outcomes in accordance with the demands of the recent development. 


\section{Content-based Teaching}

Content-based teaching is a topic classification discussing teaching on accounting science, such as professional ethics, auditing, financial accounting, and sharia accounting. Exploration related to contentbased teaching shows that the most frequently studied topics were respectively ethics $(n=67,59 \%)$, financial accounting $(n=14,12 \%)$, auditing $(n=12,11 \%)$, managerial accounting $(n=2,2 \%)$, investment management $(\mathrm{n}=10,9 \%)$, tax $(\mathrm{n}=1,1 \%)$, public sector $(\mathrm{n}=1,1 \%)$, accounting theory $(\mathrm{n}=1,1 \%)$, accounting information systems (3\%), and Sharia accounting (2\%).

Some researchers on ethics found that the better the ethical education, the better their moral development (Hermawan \& Kokthunarina, 2018; Laily \& Anantika, 2018), while Anastasyah \& Hidayat (2017) and Mukhibad (2014) found that students taking business ethical course had different ethical perceptions when compared to those never taking the course. This is because the provision of ethical content in accounting education had a significant influence on students' ethical perceptions (Sari et al., 2012). Many researchers found that ethical behavior was influenced by gender, such as that mentioned by Ernawati \& Kuncoro (2016), Himmah (2013), Yovita \& Rahmawaty (2016), yet some other researchers argued that gender did not influence an indivudual's ethical behaviors (Lestari \& Ramantha, 2019; Murtanto \& Marini, 2003; Pohan, 2012; Riasmini et al., 2018; Triani, 2011; Vitriyani \& Yanto, 2014).

In addition, the existence of sharia accounting education and character education made students tend to ethically behave (Mukhibad, 2014; Subowo, 2009). The intellectual levels for both emotional and spiritual also influenced an individual's ethical actions (Agustini \& Herawati, 2013; Kurniasari \& Budiasih, 2018; Nofianti, 2011; Pratama \& Astika, 2019; Riasning et al., 2017). In fact, when someone has a high religiosity level, he/she tended to develop their positive activities by considering and first thinking if they were intended to act unethically (Nikara \& Mimba, 2019; Prabandari \& Damayanthi, 2019; Wiguna \& Suryanawa, 2019).

Regarding the financial accounting, Wijaya (2016) has examined the learning frequency and question form to the Vocational High School students. The results show that test frequency had a significant influence on learning outcome because the classes conducted with more tests had higher scores than those with fewer tests. In terms of test format, essay influenced the students' learning achievements better than multiple choice questions. The other study on financial accounting found a significant relationship between accounting learning based on International Financial Reporting Standards (IFRS) on students' readiness to become educators (Raeni \& Purnami, 2013) and the level of knowledge belonging to the students (Dewi \& Dewi, 2019; Putri \& Ariyanto, 2019).

In auditing, Dalam \& Sinarti (2019) discussed intelligence level and learning behavior which influenced audit understanding level. Meanwhile, Marisan et al. (2014) did not find differences in the ethical decision made by the students who have and have not taken the auditing courses. Only few researchers have discussed teaching on managerial accounting, tax, public sector, accounting information system, sharia, and accounting theory.

When compared to the previous research, the findings of this study wre different from those of research conducted by Apostolou et al. (2017b) because the content-based teaching included the Sharia accounting and religiousity aspects. However, the research trends having similar focus were mostly on financial accounting, ethics, and auditing. Further research can develop studies with topics adapting to the needs of accounting professions and business complexity, for example by empirically examining the teaching model for each learning subtopics in accordance with the needs of the world recent businesses and industries (known as DUDI/Dunia Usaha and Dunia Industri).

\section{Educational Technology}

The articles summarized in this section focused on the technologies used to support the teaching and learning processes, for example Suhendro \& Chomsatu (2014) have implemented the online trading simulations to conduct the capital market learning. The results showed that learning using networks, the virtual trading known as the Indonesia Stock Exchange (IDX), was easier, more beneficial and interesting. This learning facilitated the students to better understand the real accounting in the context of real businesses. In addition, several researchers have also discussed the use of internet-based learning 
media (Dewi \& Astika, 2017; Mahmudah et al., 2019), the use of information technology (Hasan et al., 2019; Herawati, 2017), Edmodo (Rohmatillah \& Achadiyah, 2015), and MYOB Accounting (Mudmainnah et al., 2017) in evaluating the learning outcomes.

The results of this study show that there were two researchers empirically discussed the Enterprise Resource Planning (ERP) with System Application and Product (SAP). The ERP with SAP learning did not influence emotional intelligence and case-based learning (Harris \& Mardiyati, 2013). However, Hakim (2019) found several results in which education and training influenced the perceived ease of use and usefulness of ERP with SAP information system, perceived ease of effect on perceived usefulness and behavioral intention to use the ERP with SAP information system, while the perceived usefulness did not influence the usefulness SAP with ERP information system. The non-influencing variables were probably due to the fact that students did not know how the usefulness of SAP with ERP in the working world. Other researchers also found that some authors have discussed problems related to anxiety using a computer technology (Dewi \& Juliarsa, 2017; Fadilah \& Ali, 2013; Khristy \& Baridwan, 2011; Rustiana, 2004; Yudha \& Ramantha, 2014).

The discussion patterns on technology for learning was basically still limited $(n=27,6 \%)$. The proportions of each subcategory were technology and curricular problems $(n=15,56 \%)$, technology-based learning and evaluation $(\mathrm{n}=12,44 \%)$. However, the existing research trends on technology illustrated that there was an increase starting from the first decade to the second decade. This supported the opinion that research related to educational technology was greatly required to support the students' learning processes (Apostolou et al., 2017a; Apostolou et al., 2019; Apostolou et al., 2016). However, the findings of accounting education research in Indonesia and overseas show that research on technology was the least discussed. Even though today the students are highly capable of using technology, this opportunity should be maximally utilized to boost higher quality of accounting education. Further research is expected to examine the accounting education using the latest technological devices in accordance with the business developments. For example, studies related to knowledge and management skills on big data, analysis on business data, and blockchain technology for business decision making.

\section{Students}

There were 165 empirical articles published over the last two decades discussed approaches on students when learning. The topic on students was the most frequently studied and it was in accordance with the research conducted by Apostolou et al. (2017b). This was probably due to the easy and inexpensive research access in obtaining information. The topic classifications on student were categorized into four covering majors and careers $(n=92,56 \%)$, skills $(n=43,26 \%)$, learning and assessment approaches $(n=8.5 \%)$, and academic dishonesty $(\mathrm{n}=22,13 \%)$. The proportion of articles throughout the topic categories on was different within the first decade and second decade. The articles published in the first period had the reviews focusing on the identification of skills and careers on accounting selected by the students, such as learning styles, motivation in a career as an accountant and interest in pursuing the accounting profession education (Bawono et al., 2006; Hanifah \& Abdullah, 2001; Kustiawan \& Jaemah, 2009; Nazaruddin, 2008; Rahayuningsih, 2002; Sudaryono et al., 2005; Suryaningsum et al., 2004). The other example of research in the first decade, such as Hanifah \& Abdullah (2001), found that there was a close relationship between students' learning styles and learning models using textbooks, visits to the library, frequently practices on questions telated to their academic achievements, while in the next decade, learning has begun using the network (online) facilities (Wulandari et al., 2017).

The results of this study also found that in the second decade, the researchers began to be interested in academic fraud cases. Many reviews on academic fraud in Indonesia connected them with the fraud theory, such as using pressure, opportunity, rationalization and ability variables (Budiman, 2018; Fitriana \& Baridwan, 2012; Isgiyarta et al., 2019; Melati et al., 2018; Widianto \& Sari, 2017). Individual backgrounds such as behavior, religiosity, and spirituality apparently influenced the students' behaviors in doing academic fraud (Herlyana et al., 2017; Ikbal, 2014; Winardi et al., 2017). 
Discussion with the topic on students in major and career categories has become more dominant in the second decade, such as studying the relationship between motivation (economic motivation, quality, social, and personality) with career selection process (Asmoro et al., 2015; Dyastari \& Yadnyana, 2016; Januarti \& Chariri, 2019; Lestari \& Yadnyana, 2013; Vesperalis \& Muliartha, 2017). Some authors found a close relationship between gender and career selection (Andini, 2015; Saputra, 2018; Setyorini \& Dewi, 2015), while the cultures studied through lifestyles also influenced the career processes (Andini, 2015). This increasing research related to majors and careers may be due to the Indonesian people's low interest, especially in accounting graduates to be involved in the accounting profession (Mahayani et al., 2017; Paramita \& Sari, 2019; Suryani et al., 2018). In fact, the data obtained from the Indonesian Institute of Accountants in 2015 show that the growth related to the number of public accountants in Indonesia in terms of quantity was relatively low when compared to the other ASEAN countries (IAI, 2015).

Basically, the accounting education system still experienced various problems due to the difficulties in adapting to the environmental changes (Pathways Commission, 2015). To deal with these problems, it was necessary to develop skills by strengthening the basic literacy in terms of language, competence, character quality and skills through digital technology (Suryani et al., 2018, Pysarevskyi, 2019; World Economic Forum, 2016), which currently has been widely studied by the foreign scientists. However, the empirical research in Indonesia was still highly limited and needed further development. This was because many researchers replicated the previous research, for example the research results on classifications of skills, levels of emotional intelligence, intellectual (knowledge) and spiritual which were widely used by the accounting education researchers to see the students' learning outcomes (Agustin \& Sujana, 2018; Ariantini et al., 2017; Artana et al., 2014; Febriastuti, 2013; Gayatri \& Wirawati, 2019; Hetika et al., 2016; Sari \& Prastiti, 2012; Wahyuni \& Mulyadi, 2015). However, only few researchers conducted research related to the students' skills in using computer (Harimurti \& Astuti, 2016), students' personality types (Hamzah \& Yanto, 2015; Ristadewi et al., 2017; Sari, 2019) or analysis on environmental factors influencing the students' learning activities (Anggraini \& Sulastri, 2012; Dhamayanti, 2013; Kusmaeni \& Sulistyowati, 2017; Putriana \& Moeslihat, 2015).

When compared with the research conducted overseas, the results of this study were similar with those of the research trends on accounting education conducted by Apostolou et al (2017b). The topic classification on students has been the most popular one discussed, in which the students' learning varied over time and the researchers began discussing the topic on academic fraud. Each generation has different characteristics. Thus, educators must adapt to the existing circumstances. It is necessary to increase the educators' motivation to effectively provide qualified education in preparing the accounting careers and professions in the future.

\section{Teaching Staff (Faculty)}

The fifth topic classification is related to teaching staff (faculty), in which this topic discusses the accounting educators in both secondary schools and higher education institutions. The tabulation of topic on teaching staff $(\mathrm{n}=42)$ shows the distribution of subcategories on academic staff reflection $(\mathrm{n}=29,69 \%)$, teaching $(n=10,24 \%)$, other faculty issues $(n=2,5 \%)$, and research $(n=1,2 \%)$. The proportion of articles in the categories of research, teaching, and other faculty issues between those in the first decade and second decade did not significantly change.

The research results show that only few authors discussed the research of academic staff. Ruswidiono (2008) examined the academic culture related to the research on lecturers, in which academic culture in the forms of regulations, norms, and scientific values at universities influenced the productivity of lecturers in conducting the research. In terms of empirical research, the topic on teaching was discussed through the relationship of educators' performance and competence with motivation, field practice programs, and pedagogic competencies (Abidin, 2018; Hapsari \& Widhianningrum, 2014; Nugraha et al., 2014; Samlawi \& Yuliyanti, 2014). In addition, many researchers have discussed the academic staff reflections, such as teaching professionalism (Abiana \& Rasmini, 2019; Machfoedz, 1999; Rahayu \& Aryani, 2015), discipline (Supeni, 2014), and performance (Ardiana, 2016; Engko, 2008; Sofyani \& Nazaruddin, 2019; Trisnaningsih, 2011). 
When compared to the findings of research conducted by Apostolou et al. (2017b), the Indonesian researchers still rarely discussed research productivity empirically. This was probably due to the publication obligation which was only introduced in 2012 and renewed in 2017 (Kemendikbud, 2012; Kemenristek, 2019). Therefore, further research is required to identify the implications of accounting education research so that the quality of education will be better in the future. In addition, referring to the research conducted by Apostolou et al. (2019), the suggestions should be provided in the further research conducted on teaching staff problems are exploring factors or obstacles influencing the teaching staff when teaching accounting, for example a deeper understanding related to the workloads of teaching staff or factors in delivering materials either face-to-face in the classroom or through online platforms. Thus, the existing problems need to be further discussed so that the pedagogical approach used can build an inclusive learning environment, apart from the arising problems faced by the teaching staff.

\section{CONCLUSION}

This study aimed at determining the trends of accounting education research in Indonesia. The results indicated that there was an increase in publications in the field of accounting education. The topic on students was the most frequently discussed with the domination of quantitative research methods. When compared to the research conducted by Apostolou et al. (2019), the research performed in Indonesia was more various, but the discussions were more monotonous since following the previous research. Some results, such as data analytical methods and techniques were similarities. However, different from the previous research, this research has developed its focus with the most dominantly used theory of behavioral theory. In addition, the topic related to the content-based teaching also found the sharia accounting aspects. Over time, both local and international research has begun following the changes in the world of finance and business. Nowadays, we are considered in a very complex state of changes, thus, innovations related to the accounting education research are greatly needed to keep up with the rapid global development throughout the world. The future research is expected to analyze and review more in the field of accounting education research by utilizing the data processing devices, such as NVIVO. It is intended that the conducted research does not take a long time, is more structured, and can analyze more data. In addition, this research is still considered too broad, thus, further research can be developed by reviewing the existing findings in more details, such as including descriptive articles, instructional resources, and case studies.

\section{REFERENCES}

Acar, Merve, and Rafet Aktaş. 2018. "Research and Trends in Accounting Education from 2009 to 2016: A Content Analysis of Publication in Selected Journals." International Journal of Social Sciences and Education Research 4(2): 289-308.

Albrecht, W. Steve, and Robert J. Sack. 2000. "Accounting Education: Charting the Course through a Perilous Future." Accounting Education Series 16: 1-72.

Albrecht, W Steve, and Robert J Sack. 2001. "The Perilous Future of Accounting Education." CPA Journal

http://ezproxy.library.capella.edu/login?url=http://search.ebscohost.com/login.aspx?direct=true \&db $=$ bth $\& A N=4214607 \&$ site $=$ ehost-live $\&$ scope $=$ site.

Ameen, Elsie C., and Daryl M. Guffey. 2017. "A Citation Analysis and Review of Research Issues and Methodologies in Advances in Accounting Education: Teaching and Curriculum Innovations." Advances in Accounting Education: Teaching and Curriculum Innovations 21: 1-25. 
Apostolou, Barbara., Jack W. Dorminey, John M. Hassell, and James E. Rebele. 2017a. "Accounting Education Literature Review (2016)." Journal of Accounting Education 39: 1-31. http://dx.doi.org/10.1016/j.jaccedu.2017.03.001.

Apostolou, Barbara A., Jack W. Dorminey, John M. Hassell, and James E. Rebele. 2016. "Accounting Education Literature Review (2015)." Journal of Accounting Education 35: 1-36. http://dx.doi.org/10.1016/j.jaccedu.2016.03.002.

Apostolou, Barbara, Jack W. Dorminey, John M. Hassell, and James E. Rebele. 2015. "Accounting Education Literature Review (2013-2014)." Journal of Accounting Education 33(2): 69-127. http://dx.doi.org/10.1016/j.jaccedu.2015.04.001.

Apostolou, Barbara, Jack W. Dorminey, John M. Hassell, and Stephanie F. Watson. 2013. “Accounting Education Literature Review (2010-2012)." Journal of Accounting Education 31(2): 1-55. http://dx.doi.org/10.1016/j.jaccedu.2013.03.001.

Apostolou, Barbara, Jack W Dorminey, John M Hassell, and Anna Hickey. 2019. "Accounting Education Literature Review (2018)." Journal of Accounting Education 47: 1-27. https://doi.org/10.1016/j.jaccedu.2019.02.001.

Apostolou, Barbara, Jack W Dorminey, John M Hassell, and James E Rebele. 2017b. "Analysis of Trends in the Accounting Education Literature (1997-2016)." Journal of Accounting Education 41: 1-14. https://doi.org/10.1016/j.jaccedu.2017.09.003.

Apostolou, Barbara, Jack W Dorminey, John M Hassell, and James E Rebele. 2018. "Accounting Education Literature Review (2017)." Journal of Accounting Education 43: 1-23. https://doi.org/10.1016/j.jaccedu.2018.02.001.

Apostolou, Barbara, John M. Hassell, James E. Rebele, and Stephanie F. Watson. 2010. "Accounting Education Literature Review (2006-2009)." Journal of Accounting Education 28(3-4): 145-97. http://dx.doi.org/10.1016/j.jaccedu.2011.08.001.

Apostolou, Barbara, Stephanie F. Watson, John M. Hassell, and Sally A. Webber. 2001. "Accounting Education Literature Review (1997-1999)." Journal of Accounting Education 19(1): 1-61.

Bonner, Sarah E, James W Hesford, Wim A Van Der Stede, and S Mark Young. 2006. "The Most Influential Journals in Academic Accounting." Accounting, Organizations and Society 31: 663-85.

Botha, W.J.J. 2001. "Pre-qualification Education of Registered Accountants and Auditors in South Africa: Perspectives on Whether the Education Process Is Normatively Justifiable." Meditari Accountancy Research 9(1): 33-59.

Budiman, Nita Andriyani. 2018. "Perilaku Kecurangan Akademik Mahasiswa: Dimensi Fraud Diamond Dan Gone Theory.” Akuntabilitas: Jurnal Ilmu Akuntansi 11(1): 75-90.

Bui, Binh, and Brenda Porter. 2010. "The Expectation-Performance Gap in Accounting Education: An Exploratory Study." Accounting Education 19(1-2): 23-50.

Carnegie, Garry D., and Brad N. Potter. 2000. "Publishing Patterns in Specialist Accounting History Journals in the English Language, 1996-1999." The Academy pf Accounting Historians 27(2): 17798.

Ekasari, Kurnia, Nurafni Eltivia, Hesty Wahyuni, and Elvyra Handayani Soedarso. 2016. "Akuntan Bertrisakti Jiwa: Menciptakan Lulusan Berkompeten Dan Berdaya Saung Di Era Mea." Jurnal Akuntansi Multiparadigma 7(3): 453-67.

Emerald Group $\quad$ Publishing. $2020 . \quad$ Guides Methods Empirical." www.emeraldgrouppublishing.com/archived/research/guides/methods/empirical.htm. 
Freeman, Mark, Phil Hancock, Lyn Simpson, and Chris Sykes. 2008. Business as Usual: A Collaborative and Inclusive Investigation of Existing Resources, Strengths, Gaps and Challenges to Be Addressed for Sustainability in Teaching and Learning in Australian University Business Faculties. http://www.olt.gov.au/resource-business-as-usual-sustainability-sydney-2008.

Garfield, E. 1979. "Is Citation Analysis a Legitimate Evaluation Tool?” Scientometrics 1(4): 359-75.

Guffey, Daryl M. 2015. "Influential Global Perspectives on Accounting Education Articles, Authors, and University Faculties: A Citation Analysis." Global perspectives on accounting education 12: 12133.

Hoque, Zahirul. 2014. "20 Years of Studies on the Balanced Scorecard: Trends, Accomplishments, Gaps and Opportunities for Future Research." The British Accounting Review 46(1): 33-59. http://dx.doi.org/10.1016/j.bar.2013.10.003.

Howieson, Bryan. 2003. 35 British Accounting Review Accounting Practice in the New Millennium: Is Accounting Education Ready to Meet the Challenge?

IAI. 2015. "Peluang Dan Tantangan Akuntan Di Era MEA." Simposium Nasional Akuntansi (SNA) XVIII. http://www.iaiglobal.or.id/v03/files/file_publikasi/6. 17 Sept_Panel Session_Prof. Ilya Avianti.pdf (February 20, 2020).

Ismatullah, Ismet et al. 2016. "Analisa Pengaruh Teori Gone Fraud Terhadap Academic." Riset Akuntansi dan Keuangan Indonesia 1(2): 134-42.

Katz, J Sylvan, and Ben R Martin. 1997. "What Is Research Collaboration?” Research Policy 26: 1-18.

Kementerian Pendidikan dan Kebudayaan Direktorat Jenderal Pendidikan Tinggi. 2012. Surat Edaran Dirjen Dikti Nomor 152/E/T/2012 Tentang Publikasi Karya Ilmiah.

Kementerian Riset, Teknologi, dan Pendidikan Tinggi Republik Indonesia. 2019. Surat Edaran Nomor B/323/B.B1/SE/2019 Tentang Publikasi Karya Ilmiah Program Sarjana, Program Magister, Dan Program Doktor.

Kurniawan, Robert, and Budi Yuniarto. 2016. Analisis Regresi: Dasar Dan Penerapannya Dengan R. I. Jakarta: Kencana. https://books.google.co.id/books?id=KcYDwAAQBAJ \&pg=PR3\&dq=Analisis+regresi:+dasar+dan+penerapannya+dengan+R\&hl=id\&sa=X \&ved=0ahUKEwi1-8S_psbnAhXUzTgGHWOdBc0Q6AEIKTAA\#v=onepage\&q=Analisis regresi\%3A dasar dan penerapannya dengan $\mathrm{R} \& \mathrm{f}=\mathrm{false}$.

Lukka, Kari, and Eero Kasanen. 1996. "Is Accounting a Global or a Local Discipline? Evidence from Major Research Journals.” Accounting, Organizations and Society 21(7): 755-73.

Mahayani, Ni Made Dwi, Ni Luh Gede Erni Sulindawati, and Nyoman Trisna Herawati. 2017. "Pengaruh Persepsi, Motivasi, Minat, Dan Pengetahuan Mahasiswa Akuntansi Program S1 Tentang Pajak Terhadap Pilihan Berkarir Dibidang Perpajakan." e-Journal S1 Ak Universitas Pendidikan Ganesha 7(1): 1-11.

Mulawarman, Aji Dedi. 2008. "Pendidikan Akuntansi Berbasis Cinta: Lepas Dari Hegemoni Korporasi Menuju Pendidikan Yang Memberdayakan Dan Konsepsi Pembelajaran Yang Melampaui." Ekuitas 12(2): 142-58.

Neuman, W. Lawrence. 2014. 30 Teaching Sociology Social Research Methods: Qualitative and Quantitative Approaches. Seventh Ed. United States of America: Pearson Education Limited.

O'leary, Daniel E. 2010. "Intelligent Systems in Accounting, Finance and Management: Isi Journal and Proceeding Citations, and Research Issues from Most-Cited Papers." Intelligent systems in accounting, finance and management 17: 41-58. 
Paramita, Putu Vicky Yuliana, and Maria Mediatrix Ratna Sari. 2019. "Pengaruh Persepsi Mengenai Profesi Akuntan Publik, Motivasi, Dan Kecerdasan Adversity Terhadap Minat Menjadi Akuntan Publik.” E-Jurnal Akuntansi Universitas Udayana 26(1): 146-74.

Parker, Lee D. 2001. "Back to the Future: The Broadening Accounting Trajectory." British Accounting Review 33(4): 421-53.

Pathways Commission. 2015a. A Survey of Support for Teaching, Recognition of High-Quality Teaching, and Use of Teaching Portfolios in Accounting Programs. http://commons.aaahq.org/groups/0fa82ab56d/summary.

Pathways Commission. 2015b. In Pursuit of Accounting's Curricula of the Future. http://commons.aaahq.org/posts/c0a7037eea.

Pysarevskyi, Maksym. 2019. "16 Skills of the 21st-Century Needed for Any Student." Inovationhouse.org: 1-4. https://innovationhouse.org.ua/en/statti/16-kachestv-y-navykovneobhodymyh-studentam-xxi-veka/.

Rebele, James E. et al. 1998a. “Accounting Education Literature Review (1991-1997), Part I: Curriculum and Instructional Approaches* 1." Journal of Accounting Education 16(1): 1-51.

Rebele, James E., David E. Stout, and John M. Hassell. 1991. "A Review of Empirical Research in Accounting Education: 1985-1991.” Journal of Accounting Education 9(2): 167-231.

Rebele, James E et al. 1998b. "Accounting Education Literature Review (1991-1997), Part II: Students, Educational Technology, Assessment, and Faculty Issues." Journal of Accounting Education 16(2): 179-245.

Richter, Olaf Zawacki et al. 2020. Systematic Reviews in Educational Research - Methodology, Perspectives and Application.

Ristekdikti. 2018. "Urgensi Meneliti Saat Ini Adalah Kolaborasi." Direktorat Jenderal Sumber Daya Iptek dan Dikti. http://sumberdaya.ristekdikti.go.id/index.php/2018/05/09/urgensi-meneliti-saat-iniadalah-kolaborasi/ (March 1, 2020).

Rosenstreich, Daniela, and Ben Wooliscroft. 2009. "Measuring the Impact of Accounting Journals Using Google Scholar and the g -Index." The British Accounting Review 41: 227-39.

Rutledge, Robert, and Khondkar Karim. 2009. "Determinants of Coauthorship for the Most Productive Authors of Accounting Literature." Journal of Education for Business 84(3): 130-34.

Simlitabmas ristekdikti. 2017. "Resume Panduan Insentif Artikel." Ditjen Penguatan Riset dan Pengembangan Kementerian Riset, Teknologi, dan Pendidikan Tinggi. http://simlitabmas.ristekdikti.go.id/insentif_artikel/ (March 12, 2020).

Singleton, Tommie W, Aaron Singleton, Jack Bologna, and Robert Lindquist. 2007. Fraud Auditing and Forensic Accounting / Tommie W. Singleton, Aaron J. Singleton, G. Jack Bologna, Robert J. Lindquist.

Sinta Ristekdikti. 2019. "SINTA - Science and Technology Index." http://sinta2.ristekdikti.go.id/journals?q=pendidikan+akuntansi\&search=1\&sinta=\&pub=\&city=\&is $\mathrm{sn}=($ November 22, 2019).

Sweet, M. and Moynihan, R. 2007. Improving population health: the uses of systematic review. New York: Millibank Memorial Fund.

Suber, Peter. 2015. “Open Access Overview.” Wayback Machine: 1-8. 
Suryani, Ani Wilujeng, Christine Helliar, Amanda J Carter, and John Medlin. 2018. "Shunning Careers in Public Accounting Firms: The Case of Indonesia." The British Accounting Review 50(5): 463-80. https://doi.org/10.1016/j.bar.2018.05.001.

Tirto, Djayeng. 2011. "Implementasi Kewaspadaan Nasional Terhadap Bahaya Korupsi Di Lingkungan Aparatur Pemerintahan Guna Menumbuhkan Kesadaran Hukum Dalam Rangka Ketahanan Nasional." Lembaga Ketahanan Nasional Republik Indonesia. http://lib.lemhannas.go.id/public/media/catalog/0010121500000011883/swf/1485/mobile/index.html\#p=4 (February 10, 2020).

Watson, Stephanie F., Barbara Apostolou, John M. Hassell, and Sally A. Webber. 2003. "Accounting Education Literature Review (2000-2002).” Journal of Accounting Education 21(1-2): 267-325.

Watson, Stephanie F, Barbara Apostolou, John M. Hassell, and Sally A. Webber. 2007. "Accounting Education Literature Review (2003-2005)." Journal of Accounting Education 25(1-2): 1-58.

WEF. 2016. The Future of Jobs Employment, Skills and Workforce Strategy for the Fourth Industrial Revolution. www.weforum.org.

Wisnubro. 2019. "Kolaborasi Dengan Peneliti Asing Tingkatkan Daya Saing Riset Indonesia." Jaringan Pemberitaan Pemerintah (JPP). https://jpp.go.id/humaniora/iptek/332320-kolaborasi-denganpeneliti-asing-tingkatkan-daya-saing-riset-indonesia (March 1, 2020).

Yuliansyah. 2016. Meningkatkan Response Rate Pada Penelitian Survey Suatu Study Literature. I. Jakarta: Change Publication. http://repository.lppm.unila.ac.id/1354/1/2_Meningkatkan Respon Rate Pada penelitian survey.pdf. 